\title{
Ecology of Lactobacilli in the Oral Cavity: A Review of Literature
}

\author{
C. Badet* and N.B. Thebaud
}

Université Victor Segalen Bordeaux 2, UFR d'Odontologie, 16 cours de la Marne, 33000, Bordeaux, France

\begin{abstract}
Lactobacilli appear in the oral cavity during the first years of a child's life. Their presence depends on numerous factors such as the presence of ecological niches e.g. natural anfractuosities of the teeth.

A strong correlation has been established between the saliva Lactobacillus count and dental caries, the higher the DMF index, the higher the number of children harbouring a high Lactobacillus count.

Among children, the presence of lactobacilli in coronal caries is incontestable. Among adults, lactobacilli are found in root caries.

Since 1999, taxonomical revisions make it difficult to interpret the results obtained in the numerous previous studies carried out on the identification of oral lactobacilli, but whatever the sampling method or the identification technique, the carious site or the age of sampled subjects, most species belong to the Lactobacillus casei group.
\end{abstract}

This is important because if a specific correlation can be found between few species of lactobacilli and caries a better understanding of their properties could allow the development of new tools for prevention.

Keywords: Lactobacilli, oral cavity, caries, saliva.

\section{INTRODUCTION}

The oral cavity shelters a very numerous and various microbial flora. One major actor of this complex ecosystem is the dental plaque which develops naturally on oral tissues. This biofilm shows a very complex organization that remains relatively stable with time despite regular environmental changes [1-4]. When the equilibrium is compromised and when an imbalance appears among the indigenous bacteria, pathologies such as dental caries or periodontitis could occur [5].

Historically, lactobacilli were the first microorganisms implicated in dental caries development [6].

They appear during the first years of a child's life, and are present in high numbers in saliva, on the dorsum of the tongue, mucous membranes, the hard palate, in dental plaque and, in fewer numbers, on tooth surfaces [7, 8]. The presence of lactobacilli in the oral cavity depends on numerous factors such as the presence of ecological niches e.g. natural anfractuosities of the teeth [9], partly erupted third molars or orthodontic devices [10-14].

During the last fifteen years, the Lactobacillus genus has been subjected to numerous taxonomical changes and includes at present more than 80 species [15], some of which having been found in the oral cavity. The use of molecular biology tools has cast doubt over the conventional classification. The taxonomy of lactobacilli is not easy because a lot of different Gram + bacilli are grouped together under this name (GC \% from 32 to 53\%). The analysis of ARNr 16S sequences of various species shows that they belong to three

*Address correspondence to this author at the UFR d'Odontologie, 16 cours de la Marne 33000 Bordeaux, France, Tel: 335575730 07; Fax: 33557 5730 10; E-mail: cecile.badet@odonto.u-bordeaux2.fr phylogenetically separate groups, apart from their morphological and physiological characteristics [16].

These taxonomical revisions make it difficult to interpret the results obtained in the numerous previous studies carried out on the identification of oral lactobacilli and the huge range of methods and results of these works justifies this review.

On the other hand, despite these disparate results, the salivary Lactobacillus count is used in the caries prediction tests. These current tests being not much specific, it seems to be of great interest to carry out a review of the knowledge about oral lactobacilli before the elaboration of new prediction tests.

\section{Lactobacilli in Saliva}

\section{1-a. Salivary Lactobacilli in Sound Subjects}

Saliva is a link between the different tissues and structures of the oral cavity. Its analysis reveals the oral microbiological characteristics. This principle is put into practice with the «caries detection test». A correlation also exists between Lactobacillus rates in dental plaque and in saliva [17]. If bacteria from the genus Lactobacillus represent $0.1 \%$ of the total salivary flora, a critical concentration of $10^{5} \mathrm{CFU} / \mathrm{ml}$ of saliva is necessary for the detection of lactobacilli on the surface of enamel [18].

Lactobacilli absent from the oral cavity of newborns, appear during the first year of the life. Mc Carthy et al. [19] observed the presence of this species in 50\% of newborns during their first year with a rate from 200 to 30000 bact/sample.

In children without caries, the rate of salivary lactobacilli varied among the different studies. 
Carlsson et al. [20] considered that lactobacilli became regularly present in $50 \%$ of children and only since the age of 2. Later, Köhler et al. [21], indicated that $40 \%$ of a population of 3-year old children harboured lactobacilli in rates varying from $2.10^{3}$ to $4.10^{4} \mathrm{CFU} / \mathrm{ml}$ of saliva.

For older children (from 6 to 16 years old), this rate is slightly bigger (54.6\%) [22].

On the other hand, other authors reported the presence of lactobacilli in $100 \%$ of sampled children [23, 24]. One factor that could influence the rate of salivary lactobacilli during childhood is the carbohydrate intake [25-27].

In young adults, their presence is not unconditional and it depends on appropriate ecological niches. Pits and fissures or partially erupted third molars provide a retentive environment favourable to the growth of these microorganisms $[11,28]$.

Other studies have shown a significative correlation between smoking habits and salivary rates of lactobacilli [29, 30].

In old subjects, the lactobacilli rate tends to increase again $[31,32]$. Higher counts have been found in subjects harbouring removable prostheses [33] and in subjects consuming a lot of medicine [34, 35]. For Saotome et al. the measurement of the salivary lactobacilli level may be useful for the determination of oral health in elderly individuals [36].

Most of the studies were only quantitative. However, it seems to be interesting to identify the lactobacilli species present in the oral cavity of sound subjects in order to make appropriate comparisons with species found in saliva, dental plaque or dentin samples of subjects with caries.

Even if the multiplicity of methods makes it difficult to identify to the species level the lactobacilli found in saliva of children and adults without caries, we can notice a predominance of the casei group (Table 1) [13, 37-39].

\section{1-b. Salivary Lactobacilli and Carious Prediction}

Evaluation of the carious risk is a long-standing concern whose aim is to target people who need intensive prevention and thus, improve the efficiency of public health programs.

The Lactobacillus count represents the number of lactobacilli present in $1 \mathrm{ml}$ of saliva $(\mathrm{CFU} / \mathrm{ml})$. It is used to determine the efficiency of dietetic measures or to evaluate the carious risk. It is used alone or associated with other parameters [40, 41]. For Granath et al. [42], it is a better criterion than the saliva rate of Streptococus mutans. A strong correlation has been established between the Lactobacillus count and caries [43-49], the higher the DMF index, the higher the number of children harbouring a high Lactobacillus count $[39,50]$.

Some studies have also been carried out in adults in order to investigate the link salivary lactobacilli / root caries. Results have shown a strong correlation between the Lactobacillus count and the presence of this kind of carious lesion [34, 51-53]. Sullivan et al. [54] estimated that the presence of streptococci or lactobacilli in dental plaque is not a better indicator of carious activity than their count in saliva. This

Table 1. Species of Lactobacilli Identified in Saliva of Sound Subjects

\begin{tabular}{|c|c|c|c|c|}
\hline Identified species & Tennpaisan and Dahlen & Smith et al. & Botha et al. & Koll-Klais et al. \\
\hline $\begin{array}{c}\text { casei group } \\
\text { L. rhamnosus. } \\
\text { L. casei } \\
\text { L. paracasei } \\
\text { L. alactosus } \\
\text { L. plantarum } \\
\text { L. acidophilus } \\
\text { L. cellobiosus } \\
\text { L.fermentum } \\
\text { L. salivarius } \\
\text { L.buchneri } \\
\text { L. pentosus } \\
\text { L. brevis } \\
\text { L. vaginalis } \\
\text { L. xylosus } \\
\text { L.oris }\end{array}$ & $\begin{array}{c}25 \% \\
5 \% \\
- \\
\text { NI } \\
1 \% \\
3 \% \\
- \\
38 \% \\
5 \% \\
\text { NI } \\
\text { NI } \\
\text { NI } \\
\text { NI } \\
\text { NI } \\
\text { NI }\end{array}$ & $\begin{array}{c}- \\
+ \\
- \\
\text { NI } \\
- \\
+ \\
- \\
+ \\
+ \\
- \\
- \\
++ \\
\text { NI } \\
\text { NI } \\
\text { NI }\end{array}$ & $\begin{array}{c}- \\
29 \% \\
- \\
\mathrm{NI} \\
1.8 \% \\
5.3 \% \\
- \\
- \\
46.3 \% \\
- \\
- \\
5.5 \% \\
\mathrm{NI} \\
\mathrm{NI} \\
\mathrm{NI}\end{array}$ & $\begin{array}{c}18 \% \\
- \\
36 \% \\
- \\
36 \% \\
9 \% \\
- \\
64 \% \\
27 \% \\
- \\
- \\
- \\
- \\
- \\
45 \%\end{array}$ \\
\hline $\begin{array}{c}\text { delbrueckii group } \\
\text { L. delbrueckii } \\
\text { L.leichmanii } \\
\text { L. gasseri } \\
\text { L. crispatus }\end{array}$ & $\begin{array}{c}- \\
\text { NI } \\
- \\
-\end{array}$ & $\begin{array}{c}+ \\
\text { NI } \\
- \\
\text { NI }\end{array}$ & $\begin{array}{c}- \\
\mathrm{NI} \\
1.5 \% \\
\mathrm{NI}\end{array}$ & $\begin{array}{c}9 \% \\
- \\
9 \% \\
9 \%\end{array}$ \\
\hline
\end{tabular}

NI: non identifiable with the method used. -: non recovered. 
result is confirmed by the study of Motisuki et al. who showed the significance of the sampling method [55].

Therefore, the link Lactobacillus count/ carious decay is unquestionable. However, the relationship between the Lactobacillus count and the carious activity (i.e. the number of new caries appearing during a fixed period) and thus the determination of carious risk is much more questionable.

The study of van Palenstein et al. [56] seems to support the above theoretical considerations regarding the limited potential of bacterial counts as a caries predictor. On the other hand, a low level of Lactobacillus count seems to indicate, with a good probability, a low carious activity [57-61]. The clinical significance of the Lactobacillus count is also more reliable when applied to huge samples than to one person [62]. This test also has an interesting didactic application [63].

As in studies among sound subjects, the precise identification of lactobacilli present in saliva of a patient with caries has been difficult when biochemical methods have been used. With the advent of molecular tools, this identification has become more achievable. It is of some importance to know if a link exists between some species and caries, because it will be helpful for a better understanding of the natural reservoir of lactobacilli and, perhaps, it will allow the development of new tools for the prevention of dental decay [64].

The present results show again the predominance of the $L$ .casei group [24, 65] (Table 2).

Table 2. Species of Lactobacilli Identified in Saliva of Subjects with Caries

\begin{tabular}{|c|c|c|}
\hline Identified species & Nancy et al. & Munoz-Jeldrez et al. \\
\hline \multicolumn{3}{|l|}{ casei goup } \\
\hline L. rhamnosus. & ++ & - \\
\hline L. casei & + & - \\
\hline L. paracasei & - & - \\
\hline L. alactosus & NI & - \\
\hline L. plantarum & + & $4-8 \%$ \\
\hline L. acidophilus & + & $3-24 \%$ \\
\hline L. cellobiosus & - & - \\
\hline L.fermentum & + & $1-35 \%$ \\
\hline L. salivarius & + & $5-3 \%$ \\
\hline L.buchneri & - & - \\
\hline L. pentosus & - & - \\
\hline L. brevis & - & - \\
\hline L. vaginalis & NI & - \\
\hline L. xylosus & NI & $2-29 \%$ \\
\hline \multicolumn{3}{|l|}{ delbrueckii goup } \\
\hline L. delbrueckii & + & - \\
\hline L.leichmanii & NI & - \\
\hline L. gasseri & - & - \\
\hline
\end{tabular}

\section{1-c. Influence of Some General Pathologies on Salivary Lactobacilli}

Some authors have investigated the influence of some general pathologies on the salivary lactobacilli rate. A correlation between diseases implicated in mouth dryness and the Lactobacillus count has been established. Antilla et al. [66] have demonstrated the association between the salivary Lactobacillus count and the symptoms of nervous breakdown. It therefore suggests an increased risk of dental diseases among depressed subjects, which should be recognized in their treatment. A probable factor in the correlation lactobacilli/nervous breakdown could be diet, as depressive subjects eat a lot of sweet products. Another explanation linked to a decrease in the immunological system may also be a contributing factor.

High counts of salivary lactobacilli have been related to hyposalivation or xerostomia [67, 68] . Bardow et al. described the relationships between the rate of tooth demineralisation and medication intake, subjective feeling of dry mouth, saliva flow, saliva composition and the salivary level of lactobacilli in adults aged from 44 to 84 years. They showed that subjects with low unstimulated flow rates $(\leq 0.10 \mathrm{ml} / \mathrm{mn})$ had around 20 times more lactobacilli per $\mathrm{ml}$ of saliva than the subjects who had normal flow rates. This increase is greater in patients subjected to radiotherapy [6972].

\section{2. lactobacilli in Dental Plaque}

It is difficult, from the literature, to have an exact idea of the relationship between lactobacilli and dental plaque whether on the quantitative level or on the qualitative level. In effect, the numerous studies were carried out on different populations (age, DMF index, fluoride intake). Moreover, the sampling methods were also very varied. However, some results can be highlighted.

Some authors have noticed an increase in the rate of lactobacilli before the onset of carious lesions: this rate changes from $1 \%$ to 4 to $5 \%[73,74]$.

Even if lactobacilli have been reported to be less detectable in the dental plaque than in saliva $[55,65,75]$, quantitative studies performed in children gave interesting results.

In plaque covering sound surfaces, various rates of lactobacilli have been found in the different studies. Van Houte et al. observed in a teenager population the presence of lactobacilli in about $50 \%$ of the 2 samples; Sigurjons et al. found lactobacilli in $62 \%$ of the subjects of the experiment whereas Babaahmady et al. identified Lactobacilli in $21 \%$ of their samples [76- 78].

On the other hand, a positive correlation between the frequency of isolation of lactobacilli and the presence of white spot lesions was underscored. Beighton et al. carried out a survey in young children (3 to 4 years old); lactobacilli were isolated in $54 \%$ of children with caries and in $7 \%$ of children without caries. Matee et al. isolated lactobacilli from the dental plaque of children harbouring rampant caries and of children without caries. The number of lactobacilli was 100 fold higher in samples of children with caries [79, 80]. 
The studies performed in adult populations confirm an increase of the lactobacilli rate in dental plaque according to the presence of root caries [32, 53, 81, 82].

Qualitative studies confirmed the predominance of group casei species in dental plaque sampled on carious lesions. In children, L. casei is predominant, but, in early childhood caries, L. fermentum is the most frequently found species. The latter is also more frequently found in dental plaque samples in adults [20, 65, 83-87] (Table 3).

As adherence is one major factor in the formation of dental plaque, some authors have investigated in vitro the correlation between the presence of lactobacilli in dental plaque and their capacity to coaggregate with other species.

Wilcox et al. [88] have demonstrated that of the 7 species of lactobacilli studied, only two were capable of coaggregation and the coaggregation was restricted to streptococci. Lactobacillus salivarius strains (2/4) coaggregated with Streptococcus salivarius, Streptococcus gordonii, Streptococcus crista and tufted Streptococcus sanguis II strains. Lactobacillus fermentum (2/3) coaggregated with $S$. gordonii and $S$. sanguis. The coaggregation between L. salivarius and S. salivarius, S. gordonii or tufted $S$. sanguis II strains was mediated by a protein on the surface of the lactobacilli and was not inhibited by lactose. The coaggregation between $L$. fermentum and the streptococci was mediated by protein on the surface of the streptococci and was inhibited by lactose.

Filoche et al. [89] have shown that biofilm formation by the lactobacilli in mono-culture was poor. In coculture with Actinomyces species the amount of L. rhamnosus increased 7-20 times and L. plantarum 4-7 times compared to its mono-culture biofilm. $S$. mutans also promoted substantial biofilm growth of lactobacilli but $V$. parvula had no effect. The authors conclude that these Actinomyces species promoted growth of key Lactobacillus species in a biofilm, as $\operatorname{did} S$. mutans to a lesser extent, and that the ability of indi- vidual bacteria to form mono-culture biofilms is not necessarily an indicator of their survival and pathogenic potential in a complex multispecies biofilm community.

\section{Lactobacilli on Mucous Surfaces}

Lactobacilli can also be present in great number on the surfaces of the tongue and the mucous [8, 73]. Michalek et al. [90] have shown that Lactobacillus casei selectively colonize soft tissues of the tongue in gnobiotic rats. Ahumada et al. [91] characterized lactobacilli from the tongue surface and the gums in children harbouring dental decay. 31 different species were identified; $78 \%$ came from the tongue and $22 \%$ from gums. The predominant strictly homofermentative species is L. delbrueckii; L. coryneformis and L. plantarum are the two predominant facultative heterofermentatives and $L$. brevis the dominant strictly heterofermentative. The same authors [85], using the same techniques also identified lactobacilli isolated from the tongue surface and gums in sound children. $42.3 \%$ of the lactobacilli came from the tongue and $11.8 \%$ from the gums. L. fermentum and L. plantarum are predominant on the tongue; L. rhamnosus is predominant on the gum. Ahrne et al. [92] used molecular biology tools in order to identify lactobacilli isolated from the surface of the tongue, in sound adults. L.plantarum was predominant (45\%), L.rhamnosus (24\%), L.casei 14\%), L. salivarius $(10 \%)$, L. acidopilus $(7 \%)$ L.oris $(2 \%)$, L. fermentum $(2 \%)$.

The presence of these species on oral mucous could constitute a reservoir.

\section{Lactobacilli in Carious Lesions}

The microbial populations involved in dental caries are known to be highly complex and variable and have not yet been fully identified, although key organisms are generally recognized to be associated with disease progression.

Table 3. Species of Lactobacilli Identified in Dental Plaque

\begin{tabular}{|c|c|c|c|c|c|c|c|}
\hline identified species & Carlsson et al. & Meiers et al. & Milnes and Bowden & Nancy et al. & Ahumada et al. & Schüpbach et al. & Botha et al. \\
\hline \multicolumn{8}{|l|}{ casei group } \\
\hline L. rhamnosus. & $22 \%$ & - & - & ++ & $23.1 \%$ & - & $2.4 \%$ \\
\hline L. casei & $48 \%$ & $77.8 \%$ & $6.2 \%$ & + & $7.7 \%$ & - & $18.5 \%$ \\
\hline L. paracasei & NI & - & - & - & $23.1 \%$ & - & - \\
\hline L. alactosus & $11 \%$ & - & - & NI & NI & NI & $1.2 \%$ \\
\hline L. plantarum & $\mathrm{NI}$ & + & $28 \%$ & + & $30.8 \%$ & - & $9 \%$ \\
\hline L. acidophilus & $9.6 \%$ & + & $9.3 \%$ & + & - & - & $9.2 \%$ \\
\hline L. cellobiosus & NI & - & - & + & - & - & - \\
\hline L.fermentum & $9.6 \%$ & - & $31 \%$ & + & $7.7 \%$ & + & $4.6 \%$ \\
\hline L. salivarius & $\mathrm{NI}$ & - & $12.5 \%$ & + & - & + & $36.2 \%$ \\
\hline L.buchneri & NI & - & - & - & - & - & - \\
\hline L. pentosus & NI & - & - & - & - & - & - \\
\hline L. brevis & NI & + & $12.5 \%$ & - & - & - & $9 \%$ \\
\hline L. confusus & - & - & - & NI & NI & NI & $9 \%$ \\
\hline \multicolumn{8}{|l|}{ delbrueckii group } \\
\hline L. delbrueckii & NI & + & - & + & $7.7 \%$ & - & - \\
\hline L.leichmanii & $\mathrm{NI}$ & + & - & $\mathrm{NI}$ & NI & $\mathrm{NI}$ & NI \\
\hline L. gasseri & NI & - & - & - & - & + & $13.8 \%$ \\
\hline
\end{tabular}


Miller (1890) first demonstrated the bacterial invasion of dentinal tubules of both carious and non-carious dentine and reported that the tubuli micro flora contained rods. According to Owen [6], the association lactobacilli-dentinal caries was reported by Goadby in 1899 . However, it was not until the late 1950s that experimental evidence clearly established the fundamental role of these bacteria in dental caries and in pulp and periapical disease [93]. They are now considered secondary invaders rather than initiators of the caries process [28].

The identification of lactobacilli species found in carious tissues has not been systematic. Some authors have only made a simple quantitative analysis of lactobacilli rates [83, 94-98].

Among children, the presence of lactobacilli in coronal caries is incontestable. However, they are found in less quantity than Streptococcus mutans and they are not found in incipient caries [84, 99-101]. The presence of these microorganisms is also dependant on the size of the cavity: they are more numerous in medium and large cavities [102].

Among adults, lactobacilli are found in root caries [103, 104] but also in deep dentinal caries associated with pulpitis. Hahn et al. [105] have suggested the presence of two types of carious lesions: high level lactobacilli lesions and low level lactobacilli lesions. In high level lactobacilli lesions, the progression of these bacteria from necrotic superficial dentine to the deep level is very varied.

In van Strijp et al's study [106] both sound and completely demineralized dentine were placed together in the partial prothesis of 8 individuals to test whether the type of substrate influenced the composition of the bacterial flora. The results showed that lactobacilli in the dentine specimens, was positively correlated to the lesion depth. $(10.2 \pm 13.9$ $\%)$.

The authors, according to the work of McGrady et al. [107], suggested an explanation for this observation: the presence of lactobacilli could be correlated to their affinity for dentinal collagen ( $90 \%$ of the organic phase), which remained intact despite the demineralization.

Numerous authors, using different techniques, have identified species of lactobacilli found in carious tissues [65, 86, $87,105,108-114]$. Whatever the sampling method or the identification technique, the carious site or the age of sampled subjects, most species belong to the Lactobacillus case $i$ group (Tables $\mathbf{4}$ and $\mathbf{5}$ ).

These studies have also revealed the variability of isolation frequency of lactobacilli among the carious lesions.

\section{CARIOGENIC PROPERTIES OF ORAL LACTOBA- CILLI}

Even if dental decay cannot be considered as a nutritional illness, it results from an imbalance from daily carbohydrate consumption, because the cariogenic properties of bacteria is linked to sucrose metabolism which is implicated in two pathogenic properties, adherence and acid production.

Although the adhesive properties of lactobacilli are not noteworthy, it has been shown that they were able to adhere to various cell cultures and that the mechanisms of adhesion involved a certain level of specificity.
Lactobacilli cell surfaces have an $\mathrm{S}$ layer; this protein layer has a crystalline structure and is responsible for the surface hydrophobicity. The bacteria are able to adapt their surface hydrophobicity to environmental changes $(\mathrm{pH}$, ionic strength). However, it has been demonstrated that strains with an $\mathrm{S}$ layer do not adhere better than strains without an $\mathrm{S}$ layer [115].

Some authors have studied the hydrophobicity of strains of lactobacilli isolated from dental plaque, tongue, gum and saliva in sound subjects and in patients with caries $[86,116]$. A great number of lactobacilli isolated from the tongue, the dental plaque and the saliva showed hydrophobic properties from moderate to high. L. acidophilus and paracasei are the most hydrophobic species. L.rhamnosus and L.plantarum show a high level of hydrophobicity in dental plaque, gums but they also show a low one when isolated from saliva and tongue.

The production of exopolysaccharides is a key factor in the adherence of dental biofilm. Among some lactobacilli species, it has been studied extensively in the food industry, however there are fewer studies concerning oral lactobacilli $[117,118,119]$.

If little is known on their adhesive properties, the best known determinants of cariogenicity in lactobacilli are their capacity to produce acids and their ability to grow and survive in acidic environment. These bacteria have a fermentative metabolism and according to the species, two metabolic types exist; some species use homolactic fermentation and produce only lactic acid and others, using heterolactic fermentation produce lactic acid, $\mathrm{CO}_{2}$, acetic acid or ethanol. These latter are also able to metabolize pentose and pentitols. Whatever the metabolic method used by the lactobacilli, it results in an acidification of the environment. Since the work

Table 4. Species of Lactobacilli Identified in Children's Caries

\begin{tabular}{|c|c|c|}
\hline Identified species & Nancy et al. & Marchant et al. \\
\hline \hline casei group & & \\
L. rhamnosus & ++ & $24 \%$ \\
L. casei & - & $38 \%$ \\
L. pseudoplantarum & + & $\mathrm{NI} 11 \%$ \\
L.plantarum & + & $\mathrm{NI}$ \\
L. acidophilus & + & $\mathrm{NI}$ \\
L. casei casei & + & $2 \%$ \\
L. cellobiosus & + & $34 \%$ \\
L.fermentum & + & $19 \%$ \\
L. salivarius & - & $7 \%$ \\
L.buchneri & - & $4 \%$ \\
L. pentosus & - & $7 \%$ \\
L. brevis & - & $\mathrm{NI}$ \\
\hline delbrueckii group & & $\mathrm{NI}$ \\
L. delbrueckii & + & $\mathrm{NI}$ \\
L.leichmanii & & \\
& & \\
\hline
\end{tabular}


Table 5. Species of Lactobacilli Identified in Adult's Caries

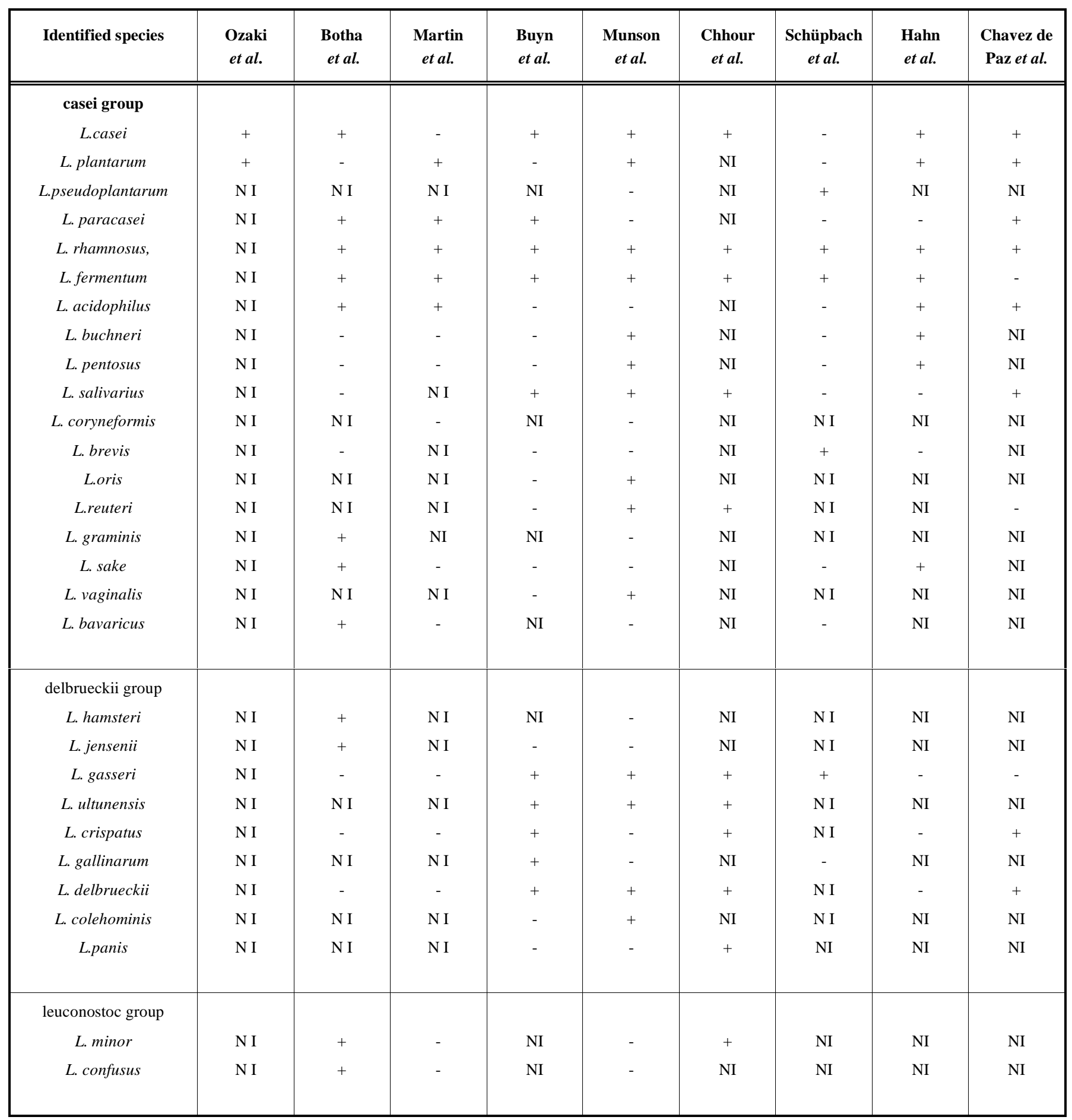

NI: non identified.

of Stephan, numerous studies have shown not only the acidogenic capacities of lactobacilli but also their acid tolerance. These bacteria can cause a decrease in environmental $\mathrm{pH}$ until values are less than 4.5 [120-124]. These species are able to survive in a $\mathrm{pH}$ up to 2.2 [125-127].

In order to limit this cariogenic potential, the use of sugar substitutes such as polyols has been recommended [128, 129]. Numerous studies have given contradictory results on lactobacilli's capacity to ferment sorbitol or xylitol. Some authors have shown that sorbitol was not fermented by lactobacilli [130] but, in other studies these bacteria were able to metabolize this polyol, often slower than sucrose, but the final $\mathrm{pH}$ was less than the critical value of 5.5 [124, 131134]. Although the metabolic aspect of xylitol has been mainly studied for the oral streptococci, some lactobacilli species seem to be able to ferment this polyol [124, 131, 135, 136]. However, other contradictory studies showed that lactobacilli were unable neither to grow nor to produce acids in the presence of this molecule [122, 132, 137, 138]. 
These controversial studies could raise questions about the intensive use of xylitol the in prevention of decay, since some species firstly unable to metabolize it are able to adapt and to ferment this polyol [139].

\section{Influence of Lactobacilli on Oral Health}

In some cases, lactobacilli could also play a beneficial role by inhibiting the growth of some cariogenic bacteria. Michalek et al. [90] present evidence that instead of contributing to the caries process, L. casei, if present in plaque, may reduce $S$. mutans- induced dental caries in gnobiotic rats.

Ahumada et al. [91] have shown that $36 \%$ of lactobacilli isolated from the tongue were able to inhibit the growth of S.mutans. The homofermentative group produced more inhibitive substances than the heterofermentative group. In another study, the same authors show that lactobacilli isolated in patients with active caries produced more inhibitive substances and substances active on more streptococci species (mutans, sanguis, anginosus, salivarius...).

Sookhee et al. [140] isolated in the oral cavities of sound subjects two species of lactobacilli (L. pacasei paracasei and L. rhamnosus) capable of having an antimicrobial activity against streptococci (S.mutans, S. sanguis, $S$.salivarius), Staphylococcus aureus, Actinomyces viscosus, Porphyromonas gingivalis and Candida.

These results were confirmed by the study of Koll-Klais et al. [141], in which $69 \%$ of tested lactobacilli inhibited $S$. mutans, $88 \%$ Actinobacillus actinomycetemcomitans, $82 \%$ Porphyromonas gingivalis and $65 \%$ Prevotella intermedia. The greatest antimicrobial activity was associated to Lactobacillus paracasei, Lactobacillus plantarum, Lactobacillus rhamnosus, and Lactobacillus salivarius. Strains isolated in periodontically sound patients showed the lowest antimicrobial activity against $S$. mutans than the strains isolated in patients with chronic periodontitis. Ishikawa et al. [142] reported that in an in vitro co culture system, L. salivarius inhibited Porphyromonas gingivalis, Prevotella intemedia and Prevotella nigrescens within $24 \mathrm{~h}$. These authors have also carried out a clinical study showing that dayly intake of tablets containing L.salivarius decreased the number of anaerobic rods in saliva after 4 weeks of administration.

Another effect is the inhibition of adherence, a major cariogenic factor of $S$. mutans. L. fermentum and its culture supernatant inhibit the production of water insoluble glucan by $S$. mutans. The growth of S.mutans is not inhibited but its in vitro adherence is totally inhibited [143]. Recently, Simark-Mattsson et al. have demonstrated that oral lactobacilli, capable of inhibiting MS in vitro, occurred naturally in healthy young subjects [144].

This possible protective activity has been partially confirmed by some recent reports on probiotics effects on oral microflora. Probiotics are food ingredients with a sufficient number of viable microorganisms that are beneficial to the health of the host. They are especially known for improving intestinal microbial health and have been used extensively in fermented milk products such as yoghurt for many years. The most frequently used bacteria in these food products include lactobacilli and bifidobacteria (Bifidobacterium bifidum).
Some authors have investigated the role of lactobacilli as probiotics in oral health. According to Bussher et al. L. acidophilus and L. casei present in yoghurts can colonize the oral cavity because they are able to adhere to enamel. A one week consumption of this yoghurt caused a removal of other lactobacilli in dental plaque and in saliva. Näse et al. showed that long-term consumption of milk containing LGG caused a significant reduction in caries risk in day care children.

According to Petti et al. the regular consumption of this yoghurt can decrease the salivary lactobacilli and $S$. mutans rate; but, as L. bulgaricus contained in that product do not colonize the oral cavity, its effect disappears when its intake ends. Ahola et al. studied whether a short-term consumption of cheese containing LGG and Lactobacillus rhamnosus LC 705 diminishes caries-associated salivary microbial counts in young adults. This cheese seems to reduce the risk of high counts of $S$. mutans and yeasts and so, reduces the carious risk [145-149].

On the other hand, Montalto et al. [150] have shown that the administration of probiotics during a 45-day period, caused an increase of the salivary rate of lactobacilli but, the streptococci rate was not significantly modified. These authors recommend a regular surveillance of oral cavities of subjects consuming robotics. In Matsumoto et al's study [151], super infection with S. mutans MT8148R and L. salivarius LS1952R enhanced the establishment of MT8148R on the molar tooth surfaces, which resulted in an enhancement of dental caries induction there. As super infection with the two species did not enhance the establishment of LS1952R on the molar tooth surfaces, co aggregation did not appear to occur. The environment produced by L. salivariuss LS1952R may influence $S$. mutans to grow and multiply. Recently, a strain of $L$. salivarius was reported to have a robotic action against periodontopathic bacteria and mutans streptococci owing to its ability to attach to the salivary pellicle on the tooth surface [152]. Unlike previous studies, YliKnuuttila et al. [153] have shown that a strain of L. rhamnosus GG was not able to colonize the oral cavity of 56 volunteers consuming a probiotic containing drink during 14 days.

Clearly, lactobacilli play a significant role within the oral ecosystem whether oral health or carious diseases.

The multiplicity of the techniques used in the various studies does not allow the emergence of one Lactobacillus species that could be especially implicated in dental caries. However, species belonging to the casei group seem to be associated with this decay.

More precise studies could give a better understanding of the pathogenic potential of these species and could allow the development of more specific caries prediction tests.

\section{REFERENCES}

[1] Kolenbrander PE, London J. Adhere today, here tomorrow: oral bacterial adherence. J Bacteriol 1993; 175: 3247-3252.

[2] Marsh PD, Bradshaw DJ. Dental plaque as a biofilm. J Ind Microbiol 1995; 15(3): 169-75.

[3] Foster JS, Pan PC, Kolenbrander PE. Effects of antimicrobial agents on oral biofilms in a saliva-conditioned flowcell. Biofilms 2004; 1: 5-12.

[4] Kolenbrander PE, Palmer RJ Jr Human oral bacterial biofilms. In: Microbial biofilms. Ghannoum M, O'Toole GA, editors. Washington, DC: ASM press, 2004; pp. 85-117. 
[5] Liljemark W.F. and Bloomquist C. Human oral microbial ecology and dental caries and periodontal diseases. Crit Rev Oral Biol Med 1996; 7(2): 180-198.

[6] Owen OW. A study of bacterial counts (lactobacilli) in saliva related to orthodontic appliances. Amer J Orthodont 1949; 35: 672678 .

[7] Socransky SS, Manganiello SD. The oral microbiota of man from birth to senility. J Periodontol 1971; 42(8): 485-96.

[8] Straetemans MM, van Loveren C, de Soet JJ, de Graaff J, ten Cate JM. Colonization with mutans streptococci and lactobacilli and the caries experience of children after the age of five. J Dent Res 1998; 77(10): 1851-1855.

[9] Loesche WJ, Eklund S, Earnest R, Burt B. Longitudinal investigation of bacteriology of human fissure decay: epidemiological studies in molars shortly after eruption. Infect Immun 1984; 46(3): 765 772.

[10] Sakamaki ST, Bahn AN. Effect of orthodontic banding on localized oral lactobacilli. J Dent Res 1968; 47(2): 275-279.

[11] Meurman JH, Rytomaa I, Murtomaa H, Turtola L. Erupting third molars and salivary lactobacilli and Streptococcus mutans counts. Scand J Dent Res 1987; 95(1): 32-36.

[12] Lundstrom F, Krasse B. Streptococcus mutans and lactobacilli frequency in orthodontic patients; the effect of chlorhexidine treatments. Eur J Orthod 1987; 9(2): 109-116

[13] Botha SJ.Oral lactobacilli isolated from teenage orthodontic patients. J Dent Assoc S Afr 1993; 48(4): 177-181.

[14] Chang HS, Walsh LJ, Freer TJ. The effect of orthodontic treatment on salivary flow, $\mathrm{pH}$, buffer capacity, and levels of mutans streptococci and lactobacilli. Aust Orthod J. 1999; 15(4): 229-234.

[15] Coeuret V., Dubernet S. Isolation, Characterisation and identification of Lactobacilli focusing mainly on cheeses and other dairy products. Lait 2003; 83: 269-306.

[16] Collins MD, Rodrigues U, Ash C, et al. Phylogenetic analysis of the genus Lactobacillus and related lactic acid bacteria as determined by reverse transcriptase sequencing of 16S rRNA. FEMS Microbiol Lett 1991; 77: 5-12.

[17] Mundorff SA, Eisenberg AD, Leverett DH, Espeland MA, Proskin HM. Correlations between numbers of microflora in plaque and saliva. Caries Res. 1990; 24(5): 312-317. Community Dent Oral Epidemiol 1991; 19(5): 302-307.

[18] Van Houte J, Green DB. Relationship between the concentration of bacteria in saliva and the colonization of teeth in humans. Infect Immun 1974; 9: 624-360.

[19] Mc Carthy C, Snyder ML, Parker RB. The indigenous oral flora of man. I: The newborn to the 1-year-old infant. Arch Oral Biol 1965; 10: 61-70.

[20] Carlsson J, Grahnen H, Jonsson G. Lactobacilli and streptococci in the mouth of children. Caries res 1975; 9: 333-339.

[21] Köhler B, Andreen I, Jonsson B. The effect of caries preventive measures in mother on dental caries and the oral presence of the bacteria Streptococcus mutans and Lactobacilli in their children. Arch Oral Biol 1984; 29(11): 879-883.

[22] Kailis DG. Carnavon studies part V. oral Lactobacillus estimations of 390 caucasian school children exposed to increased fluoride content of the town water supply in Carnavon, Western Australia (August 1965). Aust Dent J 1970; 15: 487-494.

[23] Klock B, Krasse B. Microbial and salivary condition in 9 to $12-$ year-old children. Scand J Dent Res 1977; 85: 56-63.

[24] Munoz-Jeldrez J, Martinez D. Lactobacilos de origen oral, determinacion de especies y susceptibilidad a ciertos autobioticos. Odontol Chilena 1980; 28: 86-88.

[25] Crossner CG. Variation in human oral lactobacilli following a change in sugar intake. Scand J Dent Res 1984; 92(3): 204-10.

[26] Stecksen-Blicks C. Lactobacilli and Streptococcus mutans in saliva, diet and caries increment in 8- and 13-year-old children. Scand J Dent Res 1987; 95(1): 18-26.

[27] Beighton D, Adamson A, Rugg-Gunn A. Associations between dietary intake, dental caries experience and salivary bacterial levels in 12-year-old English schoolchildren. Arch Oral Biol 1996; 41(3): 271-280.

[28] Tanzer JM, Livingston J, Thompson AM. Microbiology of primary dental caries in humans. J Dent Educ 2001; 65(10): 1028-37.

[29] Heintze U. Secretion rate, buffer effect and number of lactobacilli and Streptococcus mutans of whole saliva of cigarette smokers and nonsmokers. Scand J Dent Res 1984; 92(4): 294-301.
[30] Sakki T, Knuuttila M. Controlled study of the association of smoking with lactobacilli, mutans streptococci and yeasts in saliva. Eur J Oral Sci 1996; 104(5-6): 619-622.

[31] Percival RS, Challacombe SJ, Marsh PD. Age-related microbiological changes in the salivary and plaque microflora of healthy adults. J Med Microbiol 1991; 35(1): 5-11.

[32] Fure S.A ten-year cross-sectional and follow-up study of salivary flow rates and mutans streptococci and lactobacillus counts in elderly Swedish individuals. Oral Health Prev Dent 2003; 1(3): 185194.

[33] Narhi TO, Kurki N, Ainamo A. Saliva, salivary micro-organisms, and oral health in the home-dwelling old elderly--a five-year longitudinal study. J Dent Res 1999; 78(10): 1640-1646.

[34] Beighton D, Hellyer PH, Lynch EJ, Heath MR. Salivary levels of mutans streptococci, lactobacilli, yeasts, and root caries prevalence in non-institutionalized elderly dental patients. Community Dent Oral Epidemiol 1991; 19(5): 302-7.

[35] Guivante-Nabet C, Berenholc C, Berdal A. Caries activity and associated risk factors in elderly hospitalised population--15months follow-up in French institutions. Gerodontology 1999; 16(1): 47-58.

[36] Saotome Y, Tada A, Hanada N, Yoshihara A, Uematsu H, Miyazaki H, Senpuku H. relationship of cariogenic bacteria levels with periodontal status and root surface caries in elderly Japanese. Gerodontology 2006; 23: 219-225

[37] Teanpaisan R, Dahlen G. Use of polymerase Chain Reaction techniques and sodium dodecyl sulphate-polyacrylamide gel electrophoresis for differenciation of oral Lactobacillus species. Oral Microbiol Immunol 2006; 21: 79-83.

[38] Smith SI, Aweh AJ, Coker AO, Savage KO, Abosede DA, Oyedeji KS. Lactobacilli in human dental caries and saliva. Microbios 2001; 105(411): 77-85.

[39] Koll-Klais P, Mandar R, Leibur E, Kjaeldgaard M. High levels of salivary lactobacilli in Estonian schoolchildren. Eur J Paediatr Dent 2004; 5(2): 107-109.

[40] Crossner CG. Salivary Lactobacillus counts in the prediction of caries activity. Community Dent Oral Epidemiol 1981; 9(4): 18290.

[41] Scheinin A, Pienihakkinen K, Tiekso J, Holmberg S, Fukuda M, Suzuki A. Multifactorial modeling for root caries prediction: 3-year follow-up results. Community Dent Oral Epidemiol 1994; 22(2): 126-129.

[42] Granath L, Cleaton-Jones P, Fatti LP, Grossman ES. Salivary lactobacilli explain dental caries better than salivary mutans streptococci in 4-5-year-old children. Scand J Dent Res 1994; 102(6): 319-323.

[43] Zickert I, Emilson CG, Krasse B. Streptococcus mutans, lactobacilli and dental health in 13-14-year-old Swedish children. Community Dent Oral Epidemiol 1982; 10(2): 77-81.

[44] Kohler B, Bjarnason S. Mutans streptococci, lactobacilli and caries prevalence in 11- and 12-year-old Icelandic children. Community Dent. Oral Epidemiol. 1987; 15(6): 332-325.

[45] Alaluusua S, Nystrom M, Gronroos L, Peck L. Caries-related microbiological findings in a group of teenagers and their parents. Caries Res 1989; 23(1): 49-55.

[46] Russell JI, MacFarlane TW, Aitchison TC, Stephen KW, Burchell CK. Caries prevalence and microbiological and salivary caries activity tests in Scottish adolescents. Community Dent Oral Epidemiol. 1990; 18(3): 120-125.

[47] Roeters J, Burgersdijk R, Truin GJ, van 't Hof M. Dental caries and its determinants in 2-to-5-year-old children. ASDC J Dent Child 1995; 62(6): 401-408.

[48] Mazengo MC, Tenovuo J, Hausen H. Dental caries in relation to diet, saliva and cariogenic microorganisms in Tanzanians of selected age groups. Community Dent Oral Epidemiol 1996; 24(3): 169-174.

[49] Shi S, Zhao Y, Hayashi Y, Yakushiji M, Machida Y. A study of the relationship between caries activity and the status of dental caries: application of the Dentocult LB method. Chin J Dent Res 1999; 2(1): 34-37.

[50] Gabris K, Nagy G, Madlena M, Denes Z, Marton S, Keszthelyi G, Banoczy J. Associations between microbiological and salivary caries activity tests and caries experience in Hungarian adolescents. Caries Res 1999; 33(3): 191-195. 
[51] Ravald N, Hamp SE, Birkhed D. Long-term evaluation of root surface caries in periodontally treated patients. J Clin Periodontol 1986; 13(8): 758-67.

[52] Emilson CG, Klock B, Sanford CB. Microbial flora associated with presence of root surface caries in periodontally treated patients. Scand. J. Dent Res 1988; 96(1): 40-49.

[53] Van Houte J, Jordan HV, Laraway R, Kent R, Soparkar PM, DePaola PF. Association of the microbial flora of dental plaque and saliva with human root-surface caries. J Dent Res 1990; 69(8): 14631468.

[54] Sullivan A, Borgstrom MK, Granath L, Nilsson G. Number of mutans streptococci or lactobacilli in a total dental plaque sample does not explain the variation in caries better than the numbers in stimulated whole saliva. Community Dent Oral Epidemiol 1996; 24(3): 159-163.

[55] Motisuki C, Lima LM, Spolidorio DM, Santos-Pinto L. Influence of sample type and collection method on Streptococcus mutans and Lactobacillus spp. counts in the oral cavity. Arch Oral Biol. 2005; 50(3): 341-5.

[56] van Palenstein Helderman WH, Mikx FH, Van't Hof MA, Truin G, Kalsbeek $\mathrm{H}$. The value of salivary bacterial counts as a supplement to past caries experience as caries predictor in children. Eur J Oral Sci 2001; 109(5): 312-315.

[57] Schröder U, Edwardsson S. Dietary habits, gingival status and occurrence of Streptococcus mutans and lactobacilli as predictors of caries in 3-year-olds in Sweden. Community Dent Oral Epidemiol 1987; 15(6): 320-324

[58] Kingman A, Little W, Gomez I, Heifetz SB, Driscoll WS, Sheats R, Supan P. Salivary levels of Streptococcus mutans and lactobacilli and dental caries experiences in a US adolescent population. Community Dent Oral Epidemiol 1988; 1 6(2): 98-103

[59] Hardie JM. Oral microbiology: current concepts in the microbiology of dental caries and periodontal disease. Br Dent J 1992; 172(7): 271-278

[60] Bowden GH. Does assessment of microbial composition of plaque/saliva allow for diagnosis of disease activity of individuals? Community Dent Oral Epidemiol 1997; 25(1): 76-81.

[61] Llena-Puy MC, Montanana-Llorens C, Forner-Navarro L. Cariogenic oral flora and its relation to dental caries. ASDC J Dent Child 2000; 67(1): 42-46.

[62] Stevenson G. Present status of programs to control dental caries by combining Lactobacillus counts and dietary restriction of carbohydrates. J Dent Educ 1971; 35(6): 377-378.

[63] Crossner CG, Unell L. Salivary Lactobacillus counts as a diagnostic and didactic tool in caries prevention. Community Dent Oral Epidemiol 1986; 14(3): 156-610.

[64] Caufield PW, Li Y, Dasanayake A, Saxena D. Diversity of lactobacilli in the oral cavities of young women with dental caries. Caries Res 2007; 41(1): 2-8.

[65] Nancy J, Dorignac G. Lactobacilli from the dentin and saliva in children. J Clin Pediat Dent 1992; 16(2): 107-111.

[66] Antilla SS, Knuuttila ML, Sakki TK. Depressive symptoms favour abundant growth of salivary lactobacilli. Psychosom Med 1999 61(4): 508-512.

[67] Loesche WJ, Schork ., Terpenning M.S., Chen YM, Stoll J. Factors which influence levels of selected organisms in saliva of older individuals. J Clin Microbiol 1995; 33: 2550-2557.

[68] Almstahl A, Wikstrom M, Carlen A, Eliasson L, Lingstrom P. Lactobacillus species in supragingival plaque in subjects with hyposalivation. Int J Dent Hyg 2004; 2(3): 143,

[69] Bardow A, Nyvad B, Nauntofte B. Relationships between medication intake, complaints of dry mouth, salivary flow rate and composition, and the rate of tooth demineralization in situ. Arch Oral Biol 2001; 46(5): 413-23

[70] Keene HJ, Fleming TJ, Toth BB. Cariogenic microflora in patients with Hodgkin's disease before and after mantle field radiotherapy. Oral Surg Oral Med Oral Pathol 1994; 78(5): 577-582.

[71] Almstahl A, Kroneld U, Tarkowski A, Wikstrom M. Oral microbial flora in Sjogren's syndrome. J Rheumatol 1999; 26(1): 110-114.

[72] Al-Nawas B, Grotz KA. Prospective study of the long term change of the oral flora after radiation therapy. Support Care Cancer 2006; 14(3): 291-296. Epub 2005 Nov 30

[73] Van Houte J, Gibbons RJ, Pulkkinen AJ. Ecology of human oral lactobacilli. Infect Immun 1972; 6(5): 723-729.
[74] Ikeda T, Sandham HJ, Bradley EL Jr. Changes in Streptococcus mutans and lactobacilli in plaque in relation to the initiation of dental caries in Negro children. Arch Oral Biol 1973; 18(4): 555-566.

[75] Teanpaisan HJ, Chondsuvivatwong V, Ratasaran C, Dahlen G. The microbiological profiles of saliva, supragingival and subgingival plaque and dental caries in adults with and without type 2 diabetes mellitus. Oral microbiol Immunol 2007; 22: 175-181

[76] Van Houte J, Aasenden R, Peebles TC. Lactobacilli in human dental plaque and saliva. J Dent Res 1981; 60: 2-5.

[77] Sigurjons H, Magnusdottir MO, Holbrook WP. Cariogenic bacteria in a longitudinal study of approximal caries. Caries Res 1995; 29(1): 42-45.

[78] Babaahmady KG, Challacombe SJ, Marsh PD, Newman HN. Ecological study of Streptococcus mutans, Streptococcus sobrinus and Lactobacillus spp. at sub-sites from approximal dental plaque from children. Caries Res 1998; 32(1): 51-58.

[79] Beighton D, Brailsford S, Samaranayake LP, Brown JP, et al. A multi-country comparison of caries-associated microflora in demographically diverse children. Community Dent Health 2004; 21(1 Suppl): 96-101

[80] Matee MI, Mikx FH, Maselle SY, Van Palenstein Helderman WH Mutans streptococci and lactobacilli in breast-fed children with rampant caries. Caries Res 1992; 26(3): 183-187.

[81] Ellen RP, Banting DW, Fillery ED. Streptococcus mutans and Lactobacillus detection in the assessment of dental root surface caries risk. . Dent Res 1985; 64(10): 1245-1249.

[82] Bowden GH, Ekstrand J, McNaughton B, Challacombe SJ. Association of selected bacteria with the lesions of root surface caries. Oral Microbiol Immunol 1990; 5(6): 346-351.

[83] Meiers JC, Schachtele CF. The efect of an antibacterial solution on the microflora of human incipient fissure caries. J Dent Res 1984 6.

[84] Milnes AR, Bowden GH. The microflora associated with developing lesions of nursing caries. Caries Res 1985; 19(4): 289-297.

[85] Ahumada $M$ del C, Bru E, Colloca ME, Lopez ME, NaderMaciasME. Characterization of lactobacilli isolated from the tongue and gum. Anaerobe 1999; 5: 129-135.

[86] Schüpbach P, Osterwalder V, Guggenheim B. Human root caries: microbiota of a limited number of root caries lesions. Caries Res 1996; 30(1): 52-64.

[87] Botha SJ, Boy SC, Botha FS, Senekal R. Lactobacillus species associated with active caries lesions. J Dent Assoc S Afr 1998; 53(1): 3-6.

[88] Willcox MD, Patrikakis M, Harty DW, Loo CY, Knox KW. Coaggregation of oral lactobacilli with streptococci from the oral cavity. Oral Microbiol Immunol 1993; 8(5): 319-321.

[89] Filoche SK, Anderson SA, Sissons CH. Biofilm growth of Lactobacillus species is promoted by Actinomyces species and Streptococcus mutans. Oral Microbiol Immunol 2004; 19(5): 322-326.

[90] Michalek SM, Hirasawa M, Hiroshi K, Kuniyasu O, Mcghee J R. Oral ecology and virulence of Lactobacillus casei and Streptococcus mutans in Gnotobiotic Rats. Infect Immun 1981; 33 (3): 690696.

[91] Ahumada M del C, Bru E, Colloca ME, Lopez ME, NaderMaciasME. Lactobacilli isolation from dental plaque and saliva of a group of patients with caries and characterization of their surface properties. Anaerobe 2001; 7: 71-77.

[92] Ahrne S, Nobaek S, Jeppsson B, Adlerberth I, Wold AE, Molin G The normal Lactobacillus flora of healthy human rectal and oral mucosa. J Appl Microbiol 1998 ; 85(1): 88-94.

[93] Hemmens ES, Blayney JR, Bradel SF, Harrison RW. The microbiologic flora of the dental plaque in relation to the beginning of caries. J Dent Res 1946; 25: 195.

[94] Burnett GW and Sherp HW. Bacteriological studies of the advancing dentinal lesion. J Dent Res 1951; 30(6): 766-777.

[95] Canby CP, Burnett GW. Microorganisms of deep dentinal caries. J Dent Res 1960; 39(4): 684-685.

[96] Camilleri GE, Bowen WH. Classification of lactobacilli isolated from human carious dentin. J Dent Res 1963; 42(5): 1104-1105.

[97] Shovlin FE, Gillis RE. Biochemical and antigenic studies of lactobacilli isolated from deep dentinal caries. J Dent Res 1969; 48(3): 356-360.

[98] McKay GS. The histology and microbiology of accute occlusal dentine lesions in human permanent molar teeth. Arch Oral Biol 1976; 21: 51-58 
[99] Boyar RM, Bowden GH. The microflora associated with the progression of incipient carious lesions of children living in a waterfluoridated area. Caries Res 1985; 19(4): 298-306.

[100] de Soet JJ, Weerheijm KL, van Amerongen WE, de Graaff J. A comparison of the microbial flora in carious dentine of clinically detectable and undetectable occlusal lesions. Caries Res 1995; 29(1): 46-49.

[101] Ayna B, Celenk S, Atakul F, Sezgin B, Ozekinci T Evaluation of clinical and microbiological features of deep carious lesions in primary molars. J Dent Child 2003; 70(1): 15-8

[102] Bonecker M, Grossman E, Cleaton-Jones PE, Parak R. Clinical, histological and microbiological study of hand-excavated carious dentine in extracted permanent teeth. SADJ 2003; 58(7): 273-278.

[103] Brown LR, Billings RJ, Kaster AG. Quantitative comparisons of potentially cariogenic microorganisms cultured from non carious and carious root and coronal tooth surfaces. Infect Immun 1986; 51(3): 765-770.

[104] Beighton D, Lynch E. Comparison of selected microflora of plaque and underlying carious dentine associated with primary root caries lesions. Caries Res 1995; 29(2): 154-158.

[105] Hahn CL, Falkler WA Jr, Minah GE. Microbiological studies of carious dentine from human teeth with irreversible pulpitis. Arch Oral Biol 1991; 36(2): 147-153.

[106] van Strijp, AJP, van Steenbergen TJM, ten Cate JM. Bacterial colonization of mineralized and completely demineralized dentine in situ. Caries Res 1997; 31: 349-355.

[107] McGrady JA, Butcher WG, Beighton D, Switalski LM. Specific and charge interactions mediate collagen recognition by oral lactobacilli. J Dent Res 1995; 74(2): 649-657.

[108] Marchant S, Brailsford SR, Twomey AC, Roberts GJ, Beighton D. The predominant microflora of nursing caries lesions. Caries Res 2001; 35(6): 397-406.

[109] Ozaki K, Matsuo T, Nakae H, Noiri Y, Yoshiyama M, Ebisu S. A quantitative comparison of selected bacteria in human carious dentine by microscopic counts. Carie Res1994; 28(3): 137-145.

[110] Martin FE, Nadkarni MA, Jacques NA, Hunter N. Quantitative microbiological study of human carious dentine by culture and real-time PCR: association of anaerobes with histopathological changes in chronic pulpitis. J Clin Microbiol 2002; 40(5): 16981704.

[111] Byun R, Nadkarni MA, Chhour KL, Martin FE, Jacques NA, Hunter N. Quantitative analysis of diverse Lactobacillus species present in advanced dental caries. J Clin Microbiol 2004; 42(7): 3128-3136.

[112] Munson MA, Banerjee A, Watson TF, Wade WG. Molecular analysis of the microflora associated with dental caries. J Clin Microbiol 2004; 42(7): 3023-3029.

[113] Chhour KL, Nadkarni MA, Byun R, Martin FE, Jacques NA, Hunter N. Molecular analysis of microbial diversity in advanced caries. J Clin Microbiol 2005; 43(2): 843-849.

[114] Chavez de Paz LE, Molander A, Dahlen G. Gram-positive rods prevailing in teeth with apical periodontitis undergoing root canal treatment. Int Endod J 2004; 37(9): 579-587.

[115] Vadillo-Rodriguez V, Busscher HJ, van der Mei HC, de Vries J, Norde W. Role of Lactobacillus cell surface hydrophobicity as probed by AFM in adhesion to surfaces at low and high ionic strength. Colloids Surf B Biointerfaces 2005; 41(1): 33-41.

[116] Colloca ME, Ahumada MC, Lopez ME, Nader-Macias ME.Surface properties of lactobacilli isolated from healthy subjects. Oral Dis 2000; 6(4): 227-233.

[117] De Vuyst L, Degeest B. Heteropolysaccharides from lactic acid bacteria. FEMS Microbio Rev 1999; 23(2): 153-177.

[118] Lipinski T, Jones C, Lemercinier X, Korzeniowska-Kowal A, Strus M, Rybka J, Gamian A, Heczko PB. Structural analysis of the Lactobacillus rhamnosus strain KL37C exopolysaccharide. Carbohydr Res 2003; 338(7): 605-609.

[119] Harding LP, Marshall VM, Hernandez Y, et al. Structural characterisation of a highly branched exopolysaccharide produced by Lactobacillus delbrueckii subsp. bulgaricus NCFB2074. Carbohydr Res 2005; 340(6): 1107-1111.

[120] Hammond BF. Dextran production by a human oral strain of Lactobacillus casei: Arch Oral Biol 1969; 14(8): 879-890.

[121] Stephan CJ, Hemmens ES. Studies of the changes in $\mathrm{pH}$ produced by pure culture of oral microorganisms. J Dent Res 1947; 23: 1533.
[122] Frostell G. Interaction between xylitol and sorbitol in plaque metabolism. Swed Dent J 1984; 8(3): 137-46.

[123] Borgstrom MK, Sullivan A, Granath L, Nilsson G. On the pHlowering potential of lactobacilli and mutans streptococci from dental plaque related to the prevalence of caries. Community Dent Oral Epidemiol 1997; 25(2): 165-169.

[124] Badet MC, Richard B, Dorignac G. An in vitro study of the $\mathrm{pH}-$ lowering potential of salivary lactobacilli associated with dental caries. J Appl Microbiol 2001; 90(6): 1015-1018.

[125] Harper DS, Loesche WJ. Growth and acid tolerance of human dental plaque bacteria. Arch Oral Biol 1984; 29(10): 843-848.

[126] Fejerskov O. Concepts of dental caries and their consequences for understanding the disease. Community Dent Oral Epidemiol 1997; 25(1): 5-12.

[127] Svensater G, Larsson UB, Greif EC, Cvitkovitch DG, Hamilton IR. Acid tolerance response and survival by oral bacteria. Oral Microbio Immunol 1997; 12(5): 266-273.

[128] Scheinin A. Dietary sugars and sugar substitutes. Int Dent J 1973; 23(3): 427-431.

[129] Scheinin A, Makinen KK. Turku sugar studies. An overview. Acta Odontol Scand 1976; 34(6): 405-408.

[130] Shockley Te, Randles Ci, Dodd Mc. The fermentation of sorbitol by certain acidogenic oral microorganisms. J Dent Res 1956; 35(2): 233-340.

[131] Edwardsson S, Birkhed D, Mejare B. Acid production from Lycasin, maltitol, sorbitol and xylitol by oral streptococci and lactobacilli. Acta Odontol Scand 1977; 35(5): 257-63.

[132] Birkhed D, Edwardsson S, Svensson B, Moskovitz F, Frostell G. Acid production from sorbitol in human dental plaque. Arch Oral Biol 1978; 23(11): 971-975.

[133] Kalfas S, Edwardsson S. Sorbitol-fermenting predominant cultivable flora of human dental plaque in relation to sorbitol adaptation and salivary secretion rate. Oral Microbiol Immunol 1990; 5(1): 33-38.

[134] Takahashi N, Kalfas S, Yamada T. Effect of acetate on sorbitol fermentation by oral lactobacilli. Oral Microbiol Immunol 1995; 10(6): 349-354.

[135] Gallagher IH, Fussell SJ. Acidogenic fermentation of pentose alcohols by human dental plaque microorganisms. Arch Oral Biol 1979; 24(9): 673-679.

[136] London J, Chace NM. Pentitol metabolism in Lactobacillus casei. J Bacteriol 1979; 140(3): 949-954.

[137] Hayes ML, Roberts KR. The breakdown of glucose, xylitol and other sugar alcohols by human dental plaque bacteria. Arch Oral Biol 1978; 23(6): 445-451.

[138] Topitsoglou V, Birkhed D, Larsson LA, Frostell G. Effect of chewing gums containing xylitol, sorbitol or a mixture of xylitol and sorbitol on plaque formation, $\mathrm{pH}$ changes and acid production in human dental plaque. Caries Res 1983; 17(4): 369-378.

[139] Badet C, Richard B, Castaing-Debat M, de Flaujac PM, Dorignac G, Adaptation of salivary Lactobacillus strains to xylitol. Arch Oral Biol 2004; 49(2): 161-4.

[140] Sookhee S, Chulasiri M, Prachyabrued W. Lactic acid bacteria from healthy oral cavity of Thai volunteers: inhibition of oral pathogens. J Appl Microbiol 2001; 90(2): 172-179.

[141] Koll-Klais P, Mandar R, Leibur E, Marcotte H, Hammarstrom L, Mikelsaar M. Oral lactobacilli in chronic periodontitis and periodontal health: species composition and antimicrobial activity. Oral Microbiol Immunol 2005; 20(6): 354-61.

[142] Ishikawa H, Aiba Y, Nakanishi M, Oh-Haashi Y, Koga Y. Suppression of periodontal pathogenic bacteria in the saliva of human by the administration of lactobacillus salivariusII2711. J Jap Soc Periodontol 2003; 45: 105-112.

[143] Chung J, Ha ES, Park HR, Kim S. Isolation and characterization of Lactobacillus species inhibiting the formation of Streptococcus mutans biofilm. Oral Microbiol Immunol 2004; 19(3): 214-216.

[144] Simark-Mattsson C, Emilson CG, Hakansson EG, Jacobsson C, Roos K, Holm S. Lactobacillus-mediated interference of mutans streptococci in caries-free $v s$ caries-active subjects. Eur J Oral Sci 2007; 115(4): 308-14.

[145] Meurman JH. Probiotics: do they have a role in oral medicine and dentistry? Eur J Oral Sci 2005; 113: 188-196.

[146] Busscher HJ, Mulder AF, van der Mei HC. In vitro adhesion to enamel and in vivo colonization of tooth surfaces by lactobacilli from a bio-yoghurt. Caries Res 1999; 33(5): 403-404. 
[147] Näse L, Hatakka K, Savilahti E, et al. Effect of longtermconsumptionof a probiotic bacterium, Lactobacillus rhamnosus GG, in milk on dental caries and caries risk in children. Caries Res 2001; 35(6), 412-420.

[148] Petti S, Tarsitani G, D'Arca AS. A randomized clinical trial of the effect of yoghurt on the human salivary microflora. Arch Oral Biol 2001; 46(8): 705-712.

[149] Ahola AJ, Yli-Knuuttila H, Suomalainen T, et al. Short-term consumption of probiotic-containing cheese and its effect on dental caries risk factors Arch Oral Biol 2002; 47(11): 799-804.

[150] Montalto M, Vastola M, Marigo L, et al. Probiotic treatment increases salivary counts of lactobacilli: a double-blind, randomized, controlled study. Digestion 2004; 69(1): 53-6. Epub 2004 Jan 30
[151] Matsumoto M, Tsuji M, Sasaki H, et al. Cariogenicity of the probiotic bacterium Lactobacillus salivarius in rats. Caries Res. 2005; 39(6): 479-483.

[152] Sakabe R, Tanaka H, Sakabe J, Nakajima I, Akasaka M. Adhesion of Lactobacillus salivarius to salivary pellicle on HA. J Dent Res 2004; 83(special issue A): 3611.

[153] Yli-Knuuttila H, Snall J, Kari K, Meurman JH. Colonization of Lactobacillus rhamnosus GG in the oral cavity. Oral Microbiol Immunol 2006; 21(2): 129-131.

(C) Badet and Thebaud; Licensee Bentham Open.

This is an open access article distributed under the terms of the Creative Commons Attribution License (http://creativecommons.org/license/by/2.5/), which permits unrestrictive use, distribution, and reproduction in any medium, provided the original work is properly cited. 